\title{
Potential Environmental Risk Characteristics of PCB Transformation Products in the Environmental Medium
}

\author{
Minghao Li ${ }^{1,2,+}$, Wei He ${ }^{1,+}$, Hao Yang ${ }^{1}$, Shimei Sun ${ }^{2, *}$ and $\mathrm{Yu} \mathrm{Li}^{1, *(D)}$ \\ 1 The Moe Key Laboratory of Resources and Environmental Systems Optimization, North China Electric Power \\ University, Beijing 102206, China; lmh66@ncepu.edu.cn (M.L.); 120202232011@ncepu.edu.cn (W.H.); \\ 120212232080@ncepu.edu.cn (H.Y.) \\ 2 School of Emergency Science and Engineering, Jilin Jianzhu University, Changchun 130119, China \\ * Correspondence: sunshimei@jlju.edu.cn (S.S.); $50201549 @$ ncepu.edu.cn (Y.L.) \\ + These authors have contributed equally to the study and they receive equal credit.
}

Citation: Li, M.; He, W.; Yang, H.; Sun, S.; Li, Y. Potential Environmental Risk Characteristics of PCB Transformation Products in the Environmental Medium. Toxics 2021, 9, 213. https://doi.org/10.3390/ toxics 9090213

Academic Editors: Ruijuan Qu and Zunyao Wang

Received: 29 July 2021

Accepted: 3 September 2021

Published: 7 September 2021

Publisher's Note: MDPI stays neutral with regard to jurisdictional claims in published maps and institutional affiliations.

Copyright: (c) 2021 by the authors. Licensee MDPI, Basel, Switzerland. This article is an open access article distributed under the terms and conditions of the Creative Commons Attribution (CC BY) license (https:// creativecommons.org/licenses/by/ $4.0 /)$.
Abstract: The complementary construction of polychlorinated biphenyl (PCB) phytotoxicity and the biotoxicity 3D-QSAR model, combined with the constructed PCB environmental risk characterization model, was carried out to evaluate the persistent organic pollutant (POP) properties (toxicity (phytotoxicity and biotoxicity), bioconcentration, migration, and persistence) of PCBs and their corresponding transformation products (phytodegradation, microbial degradation, biometabolism, and photodegradation). The transformation path with a significant increase in environmental risks was analyzed. Some environmentally friendly PCB derivatives, exhibiting a good modification effect, and their parent molecules were selected as precursor molecules. Their transformation processes were simulated and evaluated for assessing the environmental risks. Some transformation products displayed increased environmental risks. The environmental risks of plant degradation products of the PCBs in the environmental media showed the maximum risk, indicating that the potential risks of the transformation products of the PCBs and their environmentally friendly derivatives could not be neglected. It is essential to further improve the ability of plants to degrade their transformation products. The improvement of some degradation products for environmentally friendly PCB derivatives indicates that the theoretical modification of a single environmental feature cannot completely control the potential environmental risks of molecules. In addition, this method can be used to analyze and evaluate environmentally friendly PCB derivatives to avoid and reduce the potential environmental and human health risks caused by environmentally friendly PCB derivatives.

Keywords: environmental risk; polychlorinated biphenyls; transformation products; three-dimensional quantitative structure-activity relationships; transformation pathways

\section{Introduction}

Polychlorinated biphenyls (PCBs) are considered persistent organic pollutants (POPs) that spread into the environment in large quantities. The global production of PCBs is estimated to be approximately 1 to 2 million tons, out of which $0.2-0.4$ million tons have produced environmental hazards [1]. The degradation or metabolism of PCBs in the environment can occur by using a variety of pathways. For instance, PCBs can be degraded to benzoic acid products by using the expression of dioxygenase degradation genes in tobacco and Arabidopsis plants [2-4]. Microorganisms can reduce the dechlorination of PCBs and degrade highly chlorinated PCBs to less-chlorinated ones [5]. In addition, microorganisms can also degrade PCBs by using cytochrome P450 enzymes (CYP450) in vivo to produce hydroxy PCB products with hydroxyl groups (OH-PCBs) [6]. The metabolism of PCBs by organisms can produce polychlorinated biphenyl methane sulfonate $\left(\mathrm{MeSO}_{2}-\mathrm{PCB}\right)$ through reactions such as oxidative substitution [7]. Under natural light radiation conditions, $\mathrm{PCBs}$ in the environment can absorb ultraviolet light and undergo 
direct photodegradation, and optically active chlorine atoms can break bonds in order to produce dechlorination products [8].

Among the multiple pathways of $\mathrm{PCB}$ transformation, the degradation or metabolites such as $\mathrm{OH}-\mathrm{PCB}$ and $\mathrm{MeSO}_{2}$-PCBs are also persistent and biotoxic [9-12]. The DNAdamaging effect of PCB-180 on rat liver was due to its metabolite $3^{\prime}-\mathrm{OH}-\mathrm{PCB} 180$, which indicates that the hydroxyl metabolites of PCBs might show a higher potential for toxicity than the parent compound [13]. OH-PCBs exhibit the potential to interfere with estrogen levels in animals and humans and even in infants, which adversely affects the developmental and reproductive functions in animals and humans [14]. In addition, $\mathrm{MeSO}_{2} \mathrm{PCBs}$ showed toxic effects and displayed stronger environmental persistence than the parent PCBs and easily enriched the food chain [15]. Therefore, further studies on the environmental risk characteristics of PCB degradation or metabolites can provide theoretical references for PCB pollution control.

This paper evaluates the environmental risks of PCB transformation products by using the following four pathways: plant degradation, microbial degradation, biometabolism, and photodegradation. The international evaluation criteria of the POPs primarily examine the following four properties of pollutants: toxicity, bioconcentration, persistence and migration. Therefore, these four characteristics were selected for evaluating the environmental risk characteristics of PCB degradation and metabolites. The POP evaluation was not defined as the toxicity evaluation receptor of pollutants. Considering that the degradation and metabolites of PCBs show estrogen interference toxicity to organisms and toxicity to plants at the same time, the phytotoxicity and biotoxicity (estrogen toxicity) of the PCBs are selected in the scope of the toxicity evaluation. In addition, the potential risk characteristics of the PCB transformation products in environmental media are primarily evaluated by using the 3D-QSAR model of the environmental risk characteristics of the PCBs.

\section{Materials and Methods}

\subsection{Data Sources}

(1) The data sources of the PCB environmental characteristics

The Stockholm Convention determines whether a chemical substance can be classified as a POP by using the following four characteristics: toxicity (phytotoxicity and biotoxicity), bioconcentration, migration, and persistence. Each characteristic requires its own characteristic parameters for evaluating the degree of each characteristic. Bioconcentration factors (BCFs) are used to represent biological enrichment. Bioconcentration as a component of risk assessment determines a meaningful BCF value for hazardous substances. It indicates the potential hazardous capacity of a substance and is the basis for assessing environmental and human risks [16]. As the evaluation criterion for the retention time of PCBs in environmental media, the half-life $\left(t_{1 / 2}\right)$ was used. The larger the $t_{1 / 2}$ of a PCB is, the longer the retention time in the environmental media will be [17]. The octanol air partition coefficient $\left(K_{\mathrm{OA}}\right)$ can respond to the migration ability of PCBs to some extent. As the $K_{\mathrm{OA}}$ decreases, PCBs easily volatilize into the air [18]. When PCBs enter the plant body, they can cause the oxidation of the cell membrane and several organelles, inhibit peroxidase activity, and damage the health of the plant body [19-21]. Therefore, this paper selected the total score of the PCB interactions with peroxidase for characterizing the phytotoxicity of the PCBs and with estrogen receptors for representing the biotoxicity (estrogen toxicity) of the PCBs. The 3D-QSAR models of the PCB bioconcentration [16], migration [17], and persistence [18] refer to the existing models. The 3D-QSAR models of PCB phytotoxicity and biotoxicity were constructed in this paper. The structures of the receptor enzyme for phytotoxicity (1CCK) and estrogen receptor enzyme (3MDJ) for estrogen toxicity were derived from the Protein Data Bank (http:/ / www1.rcsb.org; accessed on 15 February 2021).

(2) The data sources of transformation pathways and transformation products of PCBs in the environmental media 
The literature review summarized the following four transformation pathways of the PCBs [7,22-25]: plant degradation pathway, microbial degradation pathway, biometabolism pathway, and photodegradation pathway (Figure 1). The pathway for the degradation of PCBs by plants is usually a preferential attack on the non-chlorine-substituted benzene ring by dioxygenases. However, the oxidation reaction can also occur on the chlorinesubstituted ring if there is no barrier at the 2 and 3 carbon positions. For instance, first, PCBs are oxidized by dioxygenases at the 2 and 3 carbon positions in order to produce 2,3-dihydro dihydroxy PCB products; then, 2,3-dihydro dihydroxy PCBs undergo dehydrogenation reactions in order to produce 2,3-dihydroxy PCB products; thereafter, 2,3-dihydroxy PCBs undergo the meta-ring opening reaction by oxidation; finally, the resulting meta-ring opening mixture is hydrolyzed in order to produce polychlorinated benzoic acid [26]. In the microbial degradation pathway, PCBs can be oxidized to epoxides through oxidation, primarily by attacking the meta- and para-substitution sites of PCBs. The epoxidation products after meta- and para-oxidation can be directly metabolized into hydroxy PCBs by adding hydroxyl groups. In addition, PCBs can also undergo a reductive dechlorination reaction, in which the main reduction sites are meta and para, and the ortho-reaction is relatively less [27]. First, the biometabolism of PCBs is catalyzed by enzymes to produce epoxidation intermediates and carry out the methylation of PCBs by the nucleophilic reaction, dehydration, and methylation. Finally, PCBs with methyl benzenesulfonic acid were synthesized by catalytic oxidation [7]. The essence of the photodegradation of PCBs is the change of molecular energy under the action of light radiation from a low-energy state to a high-energy state, chemical bond breaking, and chemical reaction. PCBs can absorb ultraviolet light directly [28]. Fifty PCB degradation or metabolism products are summarized in Table 1.

Table 1. Summary of the degradation or metabolites of the PCBs $[7,24,29-31]$.

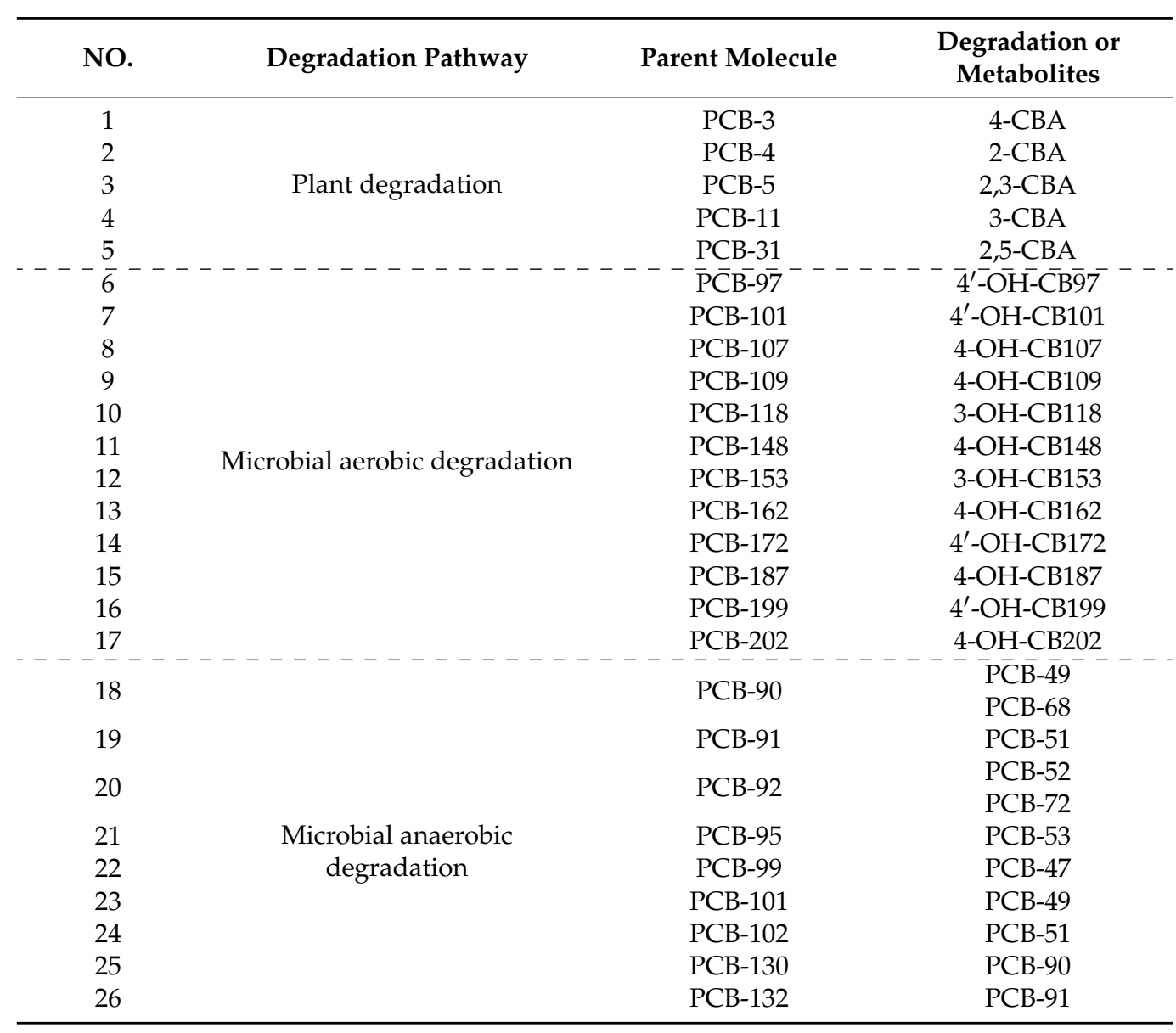


Table 1. Cont.

\begin{tabular}{|c|c|c|c|}
\hline NO. & Degradation Pathway & Parent Molecule & $\begin{array}{l}\text { Degradation or } \\
\text { Metabolites }\end{array}$ \\
\hline 27 & & PCB-135 & PCB-94 \\
\hline 28 & & PCB-137 & $\begin{array}{l}\text { PCB-90 } \\
\text { PCB-99 }\end{array}$ \\
\hline 29 & & PCB-138 & PCB-99 \\
\hline 30 & & PCB-146 & PCB-90 \\
\hline 31 & & PCB-147 & PCB-91 \\
\hline 32 & & PCB-149 & PCB-102 \\
\hline 33 & & PCB-151 & PCB-95 \\
\hline 34 & & PCB-153 & PCB-99 \\
\hline \multirow[t]{2}{*}{35} & & PCB-154 & PCB-100 \\
\hline & & & PCB-130 \\
\hline \multirow[t]{2}{*}{36} & & PCB-170 & PCB-137 \\
\hline & & & PCB-138 \\
\hline 37 & & PCB-174 & PCB-149 \\
\hline \multirow{2}{*}{38} & & \multirow{2}{*}{ PCB-180 } & PCB-153 \\
\hline & & & PCB-146 \\
\hline 39 & & PCB-183 & PCB-154 \\
\hline 40 & & PCB-187 & PCB-149 \\
\hline $4 \overline{1}$ & & $\overline{\mathrm{P}} \overline{\mathrm{CB}}-\overline{49}-$ & $\overline{3}^{\prime}-\overline{\mathrm{MeSO}} \overline{\mathrm{O}} 2-\overline{\mathrm{CB}} \overline{4} \overline{9}$ \\
\hline 42 & \multirow{5}{*}{ Biometabolism } & PCB-64 & 4-MeSO2-CB64 \\
\hline 43 & & PCB-70 & 3-MeSO2-CB70 \\
\hline 44 & & PCB-110 & 3-MeSO2-CB110 \\
\hline 45 & & PCB-149 & 4-MeSO2-CB149 \\
\hline 46 & & PCB-174 & 4-MeSO2-CB174 \\
\hline $4 \overline{7}$ & \multirow{4}{*}{ Photodegradation } & $\overline{\mathrm{P}} \overline{\mathrm{C}} \overline{\mathrm{B}}-4 \overline{7}$ & $--\overline{\mathrm{PC}} \overline{\mathrm{B}}-\overline{1} 5^{--}$ \\
\hline 48 & & PCB-40 & PCB-11 \\
\hline 49 & & PCB-101 & PCB-70 \\
\hline 50 & & PCB-171 & PCB-35 \\
\hline
\end{tabular}

\subsection{D-QSAR Model Construction of PCB Toxicity (Phytotoxicity and Estrogen Toxicity)}

In this paper, we used SYBYL-X 2.0 software for molecular structure mapping. The PCBs were studied by using the Minimize module of SYBYL-X 2.0 software. The energy convergence was limited to $0.005 \mathrm{~kJ} / \mathrm{mol}$ by using the Powell conjugate gradient method with the Gasteiger-Huckel charge, and the Tripos force field was selected for 10,000 iterations. The optimized molecules were stored in the database, and the PCBs with the highest environmental risk values in the PCB samples were used as the common skeleton for superposition.

StockholOpen was used as the molecular library of the training set. The environmental risk values of some PCBs were input into the database in turn, and the model parameters were automatically calculated using the calculate properties function. In order to establish the relationship between the structure and biological activity of the target compounds, the partial least-squares (PLS) analysis was used. By using the leave-one-out (L-O-O) method, the training set compounds were cross-validated, and the cross-validation coefficient $q^{2}$ and the best principal component $n$ were calculated. Then, by using the non-crossvalidation function (No Validation), the regression analysis was performed. Finally, to ensure a reliable 3D-QSAR estimation model for the PCB risk characteristics, the non-crossvalidation coefficient $r^{2}$, standard deviation SEE, and the test value $F$ were calculated [16]. 


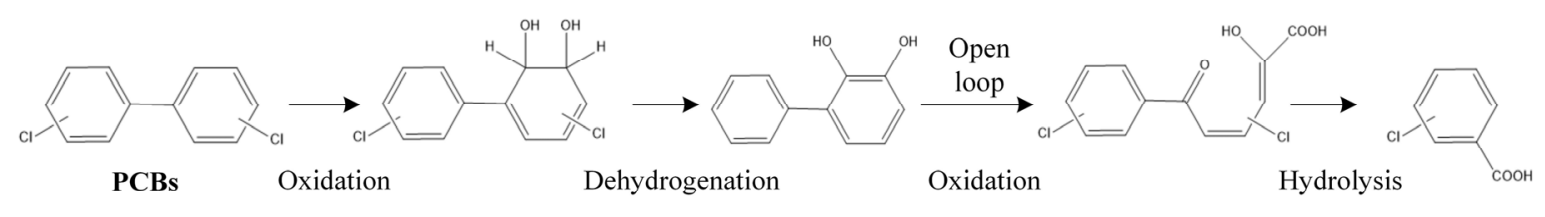

Phytodegradation of PCBs

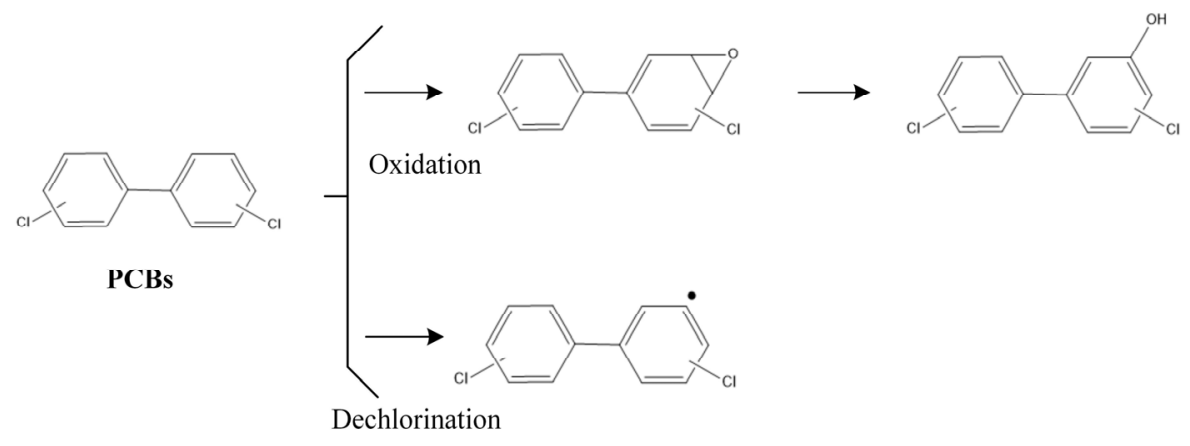

Microbial degradation of PCBs

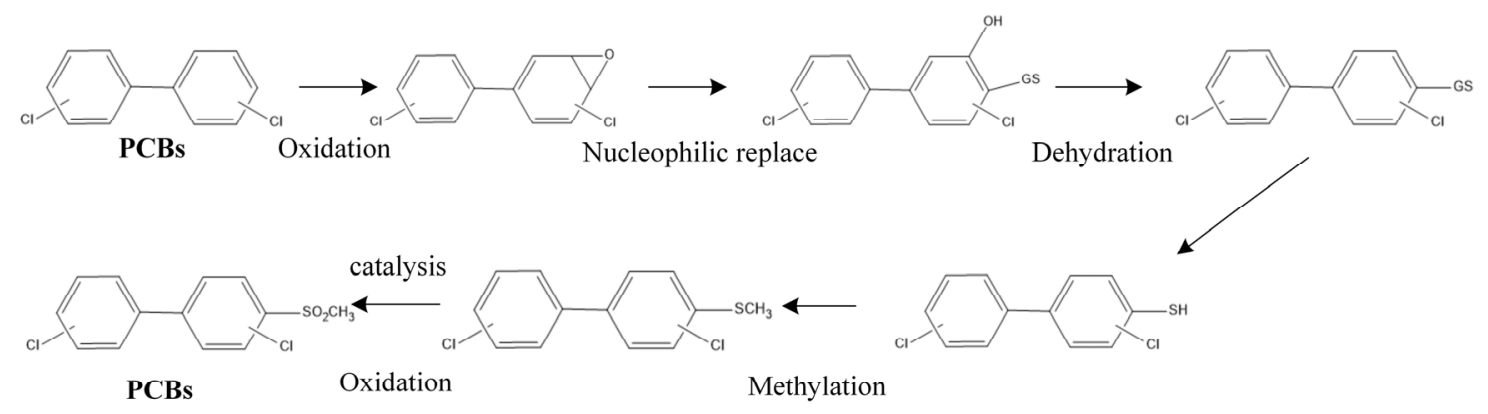

Biometabolism of PCBs

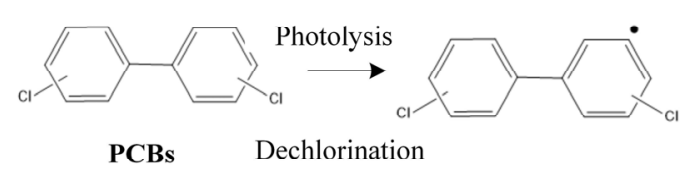

\section{Photodegradation of PCBs}

Figure 1. Schematic diagram of the four degradation or metabolic pathways of the PCBs.

\section{Results}

3D-QSAR Model Construction and Evaluation of PCB Toxicity (Phytotoxicity and Estrogen Toxicity)

Based on the CoMFA method using the total score of 70 PCBs docked with the 1CCK enzyme as the dependent variable and their molecular structures as the independent variables, the 3D-QSAR model for the phytotoxicity of the PCBs was constructed. In this process, 60 PCBs were randomly selected as the training set, and the remaining 10 molecules were selected as the test set. Based on the CoMFA method, the results showed that the best principal component $n$ and the cross-validation coefficient $q^{2}$ of the constructed 3DQSAR model were 8 and $0.695\left(q^{2}>0.5\right)$, respectively, which indicates that the model exhibited good estimation ability. The non-cross-validation coefficient $R^{2}$, the standard deviation SEE, and the test value $F$ were estimated as $0.914\left(R^{2}>0.9\right), 2.854$, and 67.952, respectively, which indicates that the constructed model fulfilled the stability requirements 
and exhibited good fitting and estimation abilities [32]. Based on the CoMFA method, Figure 2 shows the linear fit plots of the experimental and estimated values of the 3D-QSAR model for the phytotoxicity of PCBs. The results showed that all the data were concentrated around the trend line, and the $R$-value was 0.956 , which indicates that the linear fit between the experimental and estimated values was good. The model exhibited a high internal estimative power [32]. This model can be used for estimating the phytotoxicity values of PCBs and their derivatives.

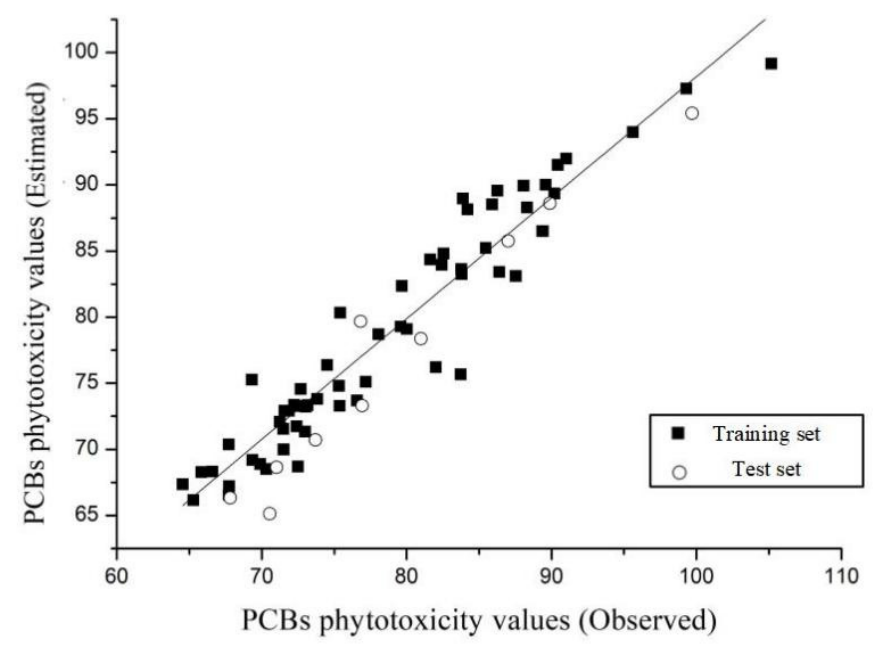

Figure 2. The plot of the observed vs. estimated phytotoxicity values of PCBs by using the 3DQSAR models.

Based on the CoMFA method, the constructed 3D-QSAR model of phytotoxicity in the PCBs estimated 70 PCBs with known experimental values. The results showed that the relative error between the experimental and estimated values of the phytotoxicity in 70 PCBs was less than 10\% [16]. The estimated values of the phytotoxicity in 209 PCBs are shown in Table 2. 
Table 2. Estimated phytotoxicity and estrogen interference values of the PCBs by using the 3D-QSAR models.

\begin{tabular}{|c|c|c|c|c|c|c|c|c|c|c|c|c|c|}
\hline \multirow{2}{*}{$\begin{array}{c}\text { PCBs } \\
\text { (IUPAC) }\end{array}$} & \multicolumn{3}{|c|}{ Phytotoxicity } & \multicolumn{3}{|c|}{ Estrogen Toxicity } & \multirow{2}{*}{$\begin{array}{c}\text { PCBs } \\
\text { (IUPAC) }\end{array}$} & \multicolumn{3}{|c|}{ Phytotoxicity } & \multicolumn{3}{|c|}{ Estrogen Toxicity } \\
\hline & Estd. & Obs. & $\begin{array}{l}\text { Relative } \\
\text { Error (\%) }\end{array}$ & Estd. & Obs. & $\begin{array}{l}\text { Relative } \\
\text { Error (\%) }\end{array}$ & & Estd. & Obs. & $\begin{array}{l}\text { Relative } \\
\text { Error (\%) }\end{array}$ & Estd. & Obs. & $\begin{array}{l}\text { Relative } \\
\text { Error (\%) }\end{array}$ \\
\hline 0 & 80.694 & & & 71.424 & & & 105 & 91.091 & & & 65.655 & & \\
\hline 1 & 80.325 & 75.426 & -6.50 & 70.958 & & & 106 & 81.145 & & & 69.353 & & \\
\hline 2 & 84.363 & 81.624 & -3.36 & 70.674 & 69.396 & -1.84 & 107 & 84.562 & & & 70.567 & & \\
\hline 3 & 83.949 & 82.426 & -1.85 & 67.889 & $65.720^{a}$ & -3.30 & 108 & 89.361 & & & 69.117 & & \\
\hline 4 & 73.802 & 73.822 & 0.03 & 63.977 & 63.512 & -0.73 & 109 & 67.583 & & & 57.749 & & \\
\hline 5 & 79.090 & 80.007 & 1.15 & 71.672 & & & 110 & 68.633 & $71.019^{a}$ & 3.36 & 61.736 & 60.469 & -2.10 \\
\hline 6 & 83.632 & 83.766 & 0.16 & 71.588 & & & 111 & 82.886 & & & 73.235 & 68.404 & -7.06 \\
\hline 7 & 83.259 & 83.786 & 0.63 & 67.399 & & & 112 & 63.621 & & & 62.042 & $62.049^{\mathrm{a}}$ & 0.01 \\
\hline 8 & 85.749 & $87.006^{a}$ & 1.44 & 68.852 & & & 113 & 70.030 & & & 64.786 & & \\
\hline 9 & 78.359 & $80.980^{a}$ & 3.24 & 72.131 & & & 114 & 83.185 & & & 66.746 & & \\
\hline 10 & 71.729 & 72.398 & 0.92 & 64.205 & & & 115 & 58.217 & & & 55.372 & & \\
\hline 11 & 83.118 & 87.533 & 5.04 & 73.814 & 73.504 & -0.42 & 116 & 61.924 & & & 58.568 & & \\
\hline 12 & 88.281 & 88.323 & 0.05 & 67.752 & & & 117 & 67.104 & & & 57.672 & 57.287 & -0.67 \\
\hline 13 & 89.938 & 88.073 & -2.12 & 67.219 & 67.002 & -0.32 & 118 & 88.524 & 85.897 & -3.06 & 65.011 & & \\
\hline 14 & 81.876 & & & 72.630 & & & 119 & 67.740 & & & 57.761 & & \\
\hline 17 & 72.967 & & & 60.820 & & & 122 & 90.103 & & & 68.870 & 68.399 & -0.69 \\
\hline 18 & 72.089 & 71.252 & -1.17 & 63.389 & & & 123 & 93.991 & 95.620 & 1.70 & 64.795 & & \\
\hline 19 & 69.084 & & & 56.327 & & & 124 & 88.268 & & & 69.449 & & \\
\hline 20 & 82.354 & 79.668 & -3.37 & 72.228 & 70.152 & -2.96 & 125 & 75.464 & & & 60.670 & & \\
\hline 21 & 82.154 & & & 68.549 & & & 126 & 99.156 & 105.165 & 5.71 & 66.748 & & \\
\hline 22 & 84.490 & & & 69.539 & & & 127 & 92.611 & & & 71.565 & & \\
\hline 23 & 76.212 & 82.007 & 7.07 & 72.676 & & & 128 & 68.328 & 66.586 & -2.62 & 58.372 & 59.488 & 1.88 \\
\hline 24 & 63.846 & & & 64.834 & 69.621 & 6.88 & 129 & 71.759 & & & 62.271 & & \\
\hline 25 & 86.493 & 89.403 & 3.25 & 67.989 & & & 130 & 74.548 & 72.689 & -2.56 & 62.574 & $59.408^{a}$ & -5.33 \\
\hline 26 & 81.368 & & & 72.709 & & & 131 & 62.701 & & & 52.006 & & \\
\hline 27 & 74.870 & & & 64.884 & & & 132 & 66.789 & & & 54.858 & & \\
\hline 28 & 88.612 & $89.893^{a}$ & 1.42 & 65.302 & & & 133 & 73.554 & & & 65.404 & & \\
\hline 29 & 80.237 & & & 67.876 & & & 134 & 62.993 & & & 56.028 & & \\
\hline 30 & 70.770 & & & 60.778 & 56.932 & -6.76 & 135 & 64.861 & & & 59.012 & & \\
\hline 31 & 83.420 & 86.392 & 3.44 & 70.012 & & & 136 & 64.381 & & & 50.250 & & \\
\hline 32 & 65.574 & & & 61.050 & & & 137 & 67.115 & & & 58.501 & & \\
\hline
\end{tabular}


Table 2. Cont.

\begin{tabular}{|c|c|c|c|c|c|c|c|c|c|c|c|c|c|}
\hline \multirow{2}{*}{$\begin{array}{c}\text { PCBs } \\
\text { (IUPAC) }\end{array}$} & \multicolumn{3}{|c|}{ Phytotoxicity } & \multicolumn{3}{|c|}{ Estrogen Toxicity } & \multirow{2}{*}{$\begin{array}{c}\text { PCBs } \\
\text { (IUPAC) }\end{array}$} & \multicolumn{3}{|c|}{ Phytotoxicity } & \multicolumn{3}{|c|}{ Estrogen Toxicity } \\
\hline & Estd. & Obs. & $\begin{array}{l}\text { Relative } \\
\text { Error (\%) }\end{array}$ & Estd. & Obs. & $\begin{array}{l}\text { Relative } \\
\text { Error (\%) }\end{array}$ & & Estd. & Obs. & $\begin{array}{l}\text { Relative } \\
\text { Error (\%) }\end{array}$ & Estd. & Obs. & $\begin{array}{l}\text { Relative } \\
\text { Error (\%) }\end{array}$ \\
\hline 33 & 89.357 & 90.196 & 0.93 & 68.142 & 67.742 & -0.59 & 138 & 68.889 & 69.900 & 1.45 & 57.865 & & \\
\hline 34 & 87.497 & & & 71.727 & & & 139 & 68.238 & & & 50.422 & & \\
\hline 35 & 86.138 & & & 69.104 & & & 140 & 60.491 & & & 48.887 & & \\
\hline 36 & 91.986 & 91.012 & -1.07 & 73.519 & & & 141 & 74.464 & & & 61.583 & & \\
\hline 37 & 91.435 & & & 64.331 & & & 142 & 70.237 & & & 52.663 & & \\
\hline 38 & 92.285 & & & 69.477 & 66.772 & -4.05 & 143 & 66.244 & & & 54.364 & & \\
\hline 39 & 91.511 & 90.431 & -1.19 & 69.204 & & & 144 & 64.648 & & & 55.168 & & \\
\hline 40 & 73.327 & 73.154 & -0.24 & 65.302 & & & 145 & 74.108 & & & 61.477 & $63.476^{\mathrm{a}}$ & 3.15 \\
\hline 41 & 68.109 & & & 61.187 & & & 146 & 75.031 & & & 60.764 & & \\
\hline 42 & 74.542 & & & 61.114 & & & 147 & 65.471 & & & 52.282 & & \\
\hline 43 & 74.076 & & & 64.081 & & & 148 & 70.797 & & & 52.261 & & \\
\hline 44 & 66.061 & & & 65.927 & & & 149 & 68.510 & & & 54.156 & 54.240 & 0.16 \\
\hline 45 & 60.125 & & & 56.469 & & & 150 & 79.539 & & & 46.136 & & \\
\hline 46 & 66.153 & 65.282 & -1.33 & 54.948 & & & 151 & 67.629 & & & 57.030 & 56.600 & -0.76 \\
\hline 47 & 65.818 & & & 57.198 & 60.010 & 4.69 & 152 & 77.851 & & & 63.524 & & \\
\hline 48 & 65.849 & & & 60.330 & & & 153 & 66.585 & 67.731 & 1.69 & 57.174 & & \\
\hline 50 & 68.467 & & & 53.531 & 51.652 & -3.64 & 155 & 74.516 & & & 64.116 & & \\
\hline 51 & 63.434 & & & 52.778 & & & 156 & 86.505 & 89.360 & 3.19 & 66.754 & & \\
\hline 52 & 67.203 & 67.751 & 0.81 & 64.519 & & & 157 & 93.025 & & & 65.739 & & \\
\hline 53 & 68.356 & & & 66.008 & & & 158 & 69.996 & & & 60.483 & $55.534^{\mathrm{a}}$ & -8.91 \\
\hline 54 & 66.777 & & & 60.121 & & & 159 & 84.798 & 82.536 & -2.74 & 69.399 & & \\
\hline 55 & 85.426 & & & 69.076 & & & 160 & 65.245 & & & 58.509 & & \\
\hline 56 & 88.107 & & & 68.780 & & & 161 & 71.927 & & & 56.126 & 57.228 & 1.93 \\
\hline 57 & 79.168 & & & 73.179 & 75.837 & 3.51 & 162 & 86.262 & & & 69.840 & & \\
\hline 58 & 86.389 & & & 72.286 & & & 163 & 66.042 & & & 64.367 & & \\
\hline 59 & 66.140 & & & 65.444 & & & 164 & 73.207 & 73.038 & -0.23 & 59.661 & & \\
\hline 60 & 87.500 & & & 66.423 & 67.218 & 1.18 & 165 & 66.114 & & & 62.462 & & \\
\hline 61 & 78.246 & & & 68.885 & & & 166 & 60.991 & & & 54.165 & & \\
\hline 62 & 65.854 & & & 60.866 & & & 167 & 90.001 & 89.597 & -0.45 & 65.217 & & \\
\hline 63 & 81.240 & & & 70.529 & & & 168 & 77.170 & & & 57.249 & & \\
\hline 64 & 64.290 & & & 57.249 & & & 169 & 95.088 & & & 67.929 & 69.672 & 2.50 \\
\hline
\end{tabular}


Table 2. Cont.

\begin{tabular}{|c|c|c|c|c|c|c|c|c|c|c|c|c|c|}
\hline \multirow{2}{*}{$\begin{array}{c}\text { PCBs } \\
\text { (IUPAC) }\end{array}$} & \multicolumn{3}{|c|}{ Phytotoxicity } & \multicolumn{3}{|c|}{ Estrogen Toxicity } & \multirow{2}{*}{$\begin{array}{c}\text { PCBs } \\
\text { (IUPAC) }\end{array}$} & \multicolumn{3}{|c|}{ Phytotoxicity } & \multicolumn{3}{|c|}{ Estrogen Toxicity } \\
\hline & Estd. & Obs. & $\begin{array}{l}\text { Relative } \\
\text { Error (\%) }\end{array}$ & Estd. & Obs. & $\begin{array}{l}\text { Relative } \\
\text { Error (\%) }\end{array}$ & & Estd. & Obs. & $\begin{array}{l}\text { Relative } \\
\text { Error (\%) }\end{array}$ & Estd. & Obs. & $\begin{array}{l}\text { Relative } \\
\text { Error (\%) }\end{array}$ \\
\hline 65 & 60.271 & & & 62.106 & 64.739 & 4.07 & 170 & 73.365 & 72.234 & -1.57 & 58.643 & & \\
\hline 66 & 92.187 & & & 64.582 & $70.824^{a}$ & 8.81 & 171 & 70.282 & & & 49.261 & & \\
\hline 67 & 83.173 & & & 68.420 & & & 172 & 69.300 & & & 61.413 & & \\
\hline 68 & 90.326 & & & 68.134 & & & 173 & 70.549 & & & 53.322 & 55.317 & 3.61 \\
\hline 69 & 74.005 & & & 61.429 & & & 174 & 70.357 & 67.737 & -3.87 & 55.179 & & \\
\hline 70 & 86.766 & & & 69.266 & 68.144 & -1.65 & 175 & 82.557 & & & 56.668 & & \\
\hline 71 & 68.635 & & & 61.179 & 58.979 & -3.73 & 176 & 71.336 & 72.986 & 2.26 & 63.146 & & \\
\hline 72 & 84.899 & & & 72.836 & 77.695 & 6.25 & 177 & 66.333 & $67.823^{a}$ & 2.20 & 52.939 & 50.357 & -5.13 \\
\hline 73 & 73.877 & & & 64.293 & & & 178 & 67.363 & & & 57.564 & & \\
\hline 74 & 85.224 & 85.467 & 0.28 & 65.771 & & & 179 & 66.274 & & & 48.973 & & \\
\hline 75 & 64.592 & & & 57.676 & & & 180 & 68.687 & 72.489 & 5.24 & 57.952 & 55.123 & -5.13 \\
\hline 76 & 91.184 & & & 68.336 & & & 181 & 73.058 & & & 49.108 & & \\
\hline 77 & 97.273 & 99.318 & 2.06 & 64.961 & & & 182 & 65.665 & & & 51.597 & & \\
\hline 78 & 95.861 & & & 70.370 & & & 183 & 71.546 & 71.487 & -0.08 & 50.906 & $52.807^{\mathrm{a}}$ & 3.60 \\
\hline 79 & 88.812 & & & 69.859 & & & 184 & 73.752 & & & 43.131 & & \\
\hline 80 & 88.972 & 83.873 & -6.08 & 74.719 & & & 185 & 75.222 & & & 53.835 & & \\
\hline 82 & 75.659 & 83.729 & 9.64 & 61.660 & 64.109 & 3.82 & 187 & 71.067 & & & 52.759 & & \\
\hline 83 & 75.123 & & & 64.490 & & & 188 & 77.819 & & & 65.671 & & \\
\hline 84 & 60.484 & & & 58.008 & & & 189 & 88.147 & 84.203 & -4.68 & 66.052 & & \\
\hline 85 & 67.346 & 64.546 & -4.34 & 57.494 & & & 190 & 67.586 & & & 59.613 & 58.962 & -1.10 \\
\hline 86 & 67.811 & & & 60.494 & & & 191 & 75.088 & 77.172 & 2.70 & 50.567 & 51.685 & 2.16 \\
\hline 87 & 68.117 & & & 62.251 & & & 192 & 67.662 & & & 58.945 & & \\
\hline 88 & 60.852 & & & 53.986 & & & 193 & 69.188 & 69.360 & 0.25 & 58.711 & & \\
\hline 89 & 61.130 & & & 52.143 & & & 194 & 73.294 & $76.926^{a}$ & 4.72 & 57.909 & & \\
\hline 90 & 73.421 & & & 60.341 & & & 195 & 69.996 & 71.502 & 2.11 & 50.303 & & \\
\hline 91 & 62.968 & & & 53.689 & & & 196 & 73.869 & & & 51.909 & & \\
\hline 92 & 64.058 & & & 65.180 & & & 197 & 76.361 & 74.519 & -2.47 & 61.428 & & \\
\hline 93 & 62.641 & & & 55.883 & & & 198 & 74.917 & & & 54.322 & & \\
\hline 94 & 71.336 & & & 55.614 & & & 199 & 73.260 & 72.533 & -1.00 & 53.729 & & \\
\hline 95 & 65.125 & $70.561^{a}$ & 7.70 & 58.455 & & & 200 & 73.676 & 76.580 & 3.79 & 62.805 & 61.690 & -1.81 \\
\hline 96 & 79.861 & & & 66.412 & & & 201 & 68.497 & 70.293 & 2.56 & 58.049 & & \\
\hline
\end{tabular}


Table 2. Cont.

\begin{tabular}{|c|c|c|c|c|c|c|c|c|c|c|c|c|c|}
\hline \multirow[b]{2}{*}{$\begin{array}{c}\text { PCBs } \\
\text { (IUPAC) }\end{array}$} & \multicolumn{3}{|c|}{ Phytotoxicity } & \multicolumn{3}{|c|}{ Estrogen Toxicity } & \multirow{2}{*}{$\begin{array}{c}\text { PCBs } \\
\text { (IUPAC) }\end{array}$} & \multicolumn{3}{|c|}{ Phytotoxicity } & \multicolumn{3}{|c|}{ Estrogen Toxicity } \\
\hline & Estd. & Obs. & $\begin{array}{l}\text { Relative } \\
\text { Error (\%) }\end{array}$ & Estd. & Obs. & $\begin{array}{l}\text { Relative } \\
\text { Error (\%) }\end{array}$ & & Estd. & Obs. & $\begin{array}{l}\text { Relative } \\
\text { Error }(\%)\end{array}$ & Estd. & Obs. & $\begin{array}{l}\text { Relative } \\
\text { Error (\%) }\end{array}$ \\
\hline 97 & 76.133 & & & 61.494 & 59.222 & -3.84 & 202 & 68.262 & 65.828 & -3.70 & 49.883 & & \\
\hline 98 & 65.547 & & & 51.651 & 52.414 & 1.46 & 203 & 78.701 & 78.053 & -0.83 & 49.585 & & \\
\hline 99 & 65.061 & & & 56.699 & & & 204 & 72.909 & $71.865^{a}$ & -1.45 & 60.753 & & \\
\hline 100 & 62.776 & & & 50.011 & & & 205 & 70.706 & 73.702 & 4.07 & 53.985 & & \\
\hline 101 & 72.904 & 71.570 & -1.86 & 61.497 & $65.198^{a}$ & 5.68 & 206 & 76.912 & & & 55.815 & $59.438^{a}$ & 6.10 \\
\hline 102 & 68.287 & & & 53.276 & & & 207 & 79.669 & $76.815^{a}$ & -3.72 & 60.496 & & \\
\hline 103 & 73.465 & & & 54.758 & & & 208 & 74.789 & 75.332 & 0.72 & 55.552 & 55.405 & -0.27 \\
\hline 104 & 69.305 & & & 62.315 & & & 209 & 79.286 & 79.575 & 0.36 & 59.179 & 59.612 & 0.73 \\
\hline
\end{tabular}

a Test set. 
In addition, the total-score of 48 PCBs docked with the 3GZX enzyme were selected for representing the estrogen toxicity, and 38 PCBs and 10 PCBs were randomly selected in the training and test sets of the model for constructing the 3D-QSAR model of estrogen toxicity. Based on the CoMFA method, the results showed that the 3D-QSAR model of estrogen toxicity in PCBs showed a good estimation ability by using the best principal component $n$ with a value of 7 and the cross-validation coefficient $q^{2}$ with a value of $0.671\left(q^{2}>0.5\right)$. The constructed model fulfilled the stability requirements and exhibited a good fitting ability (the non-cross-validation coefficient $R^{2}$ of $0.90\left(R^{2}>0.9\right)$, the standard deviation SEE, and test values $F$ of 2.509 and 38.578 , respectively) [32]. The experimental and estimated values of the test and training sets of the estrogen toxicity model in PCBs were linearly fitted (Figure 3). As shown in Figure 3, all the data were concentrated near the trend line with an $R$-value of 0.949 , which indicated a high correlation coefficient and estimate capability for the linear fit of the relationship between the experimental and estimated values [14]. This model can be used for estimating the estrogen toxicity values of PCBs and their derivatives (Figure 3). The 3D-QSAR model of estrogen toxicity in PCBs was used for estimating the estrogen toxicity values of 209 PCBs. The relative errors between the experimental and estimated values of the estrogen toxicity in 48 PCBs were less than 10\% [16].

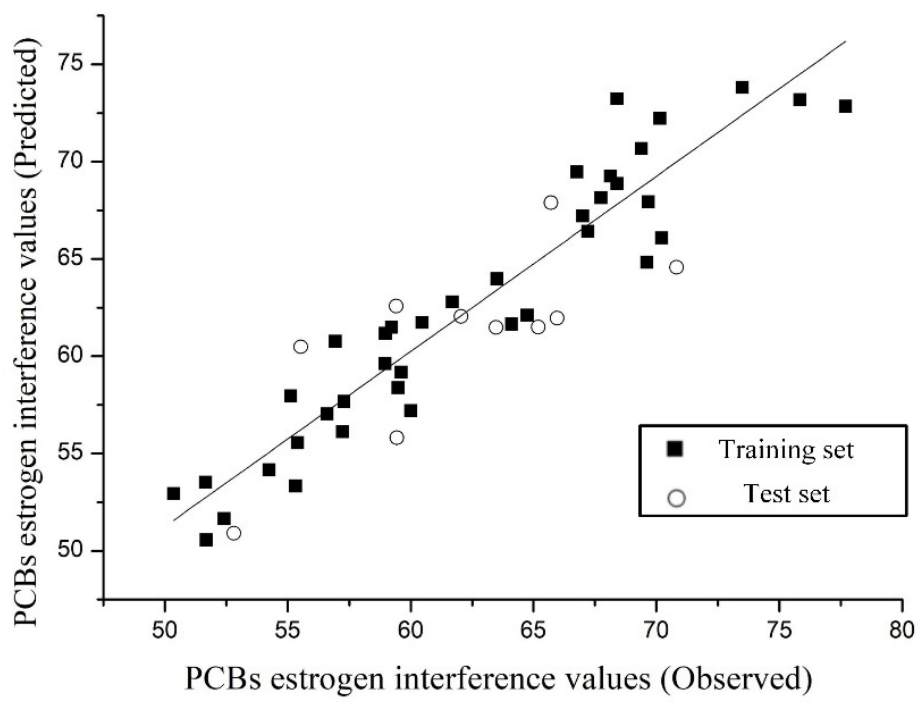

Figure 3. The plot of the observed vs. estimated estrogen interference values by the 3D-QSAR models.

\section{Discussion}

4.1. The Estimation of the Environmental Risk Characteristics of PCB Transformation Products in Environmental Media

To determine the degradation path of PCB degradation and transformation products with the greatest environmental risk, a total of 50 PCB transformation products were estimated by using the phytodegradation pathway, microbial degradation pathway, biometabolism pathway, and photodegradation pathway of the PCBs. Five kinds of environmental risk characteristics (phytotoxicity, estrogen toxicity, bioconcentration, persistence, and migration) of the PCB transformation products were evaluated. As shown in Table S1, the ranges of the phytotoxicity, estrogen toxicity, bioconcentration, persistence, and migration for the different PCB transformation products were as follows: for PCB phytodegradation products: $-1.36 \%$ to $22.92 \%,-11.01 \%$ to $8.32 \%, 22.08 \%$ to $61.26 \%, 56.87 \%$ to $421.71 \%$, and $1.22 \%$ to $32.27 \%$, respectively; for PCB microbial aerobic degradation products: $-14.46 \%$ to $17.93 \%,-10.48 \%$ to $15.48 \%,-5.40 \%$ to $9.50 \%,-37.71 \%$ to $12.31 \%$, and $-19.68 \%$ to $18.51 \%$, respectively; for PCB microbial anaerobic degradation products: $-8.82 \%$ to $32.53 \%,-5.76 \%$ to $12.92 \%,-13.09 \%$ to $4.05 \%,-25.45 \%$ to $9.64 \%$, and $-19.10 \%$ to $-3.99 \%$, respectively; for PCB biometabolism products: $-8.97 \%$ to $19.40 \%,-8.74 \%$ to $1.89 \%,-4.45 \%$ to $19.39 \%,-5.69 \%$ to $42.10 \%$, and $-2.92 \%$ to $20.42 \%$, respectively; for PCB 
photodegradation products: $13.35 \%$ to $36.06 \%, 12.63 \%$ to $40.28 \%,-22.93 \%$ to $-11.85 \%$, $-60.70 \%$ to $-15.36 \%$, and $-16.20 \%$ to $-1.89 \%$, respectively.

Figure 4 is a heat map of the environmental risk characteristics (phytotoxicity, estrogen toxicity, bioconcentration, persistence, and migration) of PCB transformation products under different degradation pathways (the phytodegradation pathway, the microbial degradation pathway, the biometabolism pathway, and the photodegradation pathway). The color of the heat map is divided into 10 levels. The higher the color level, the greater the variation range of environmental risk characteristics of PCBs degradation products. As shown in Figure 4, the region of PCBs plant degradation products has the darkest color. Combined with the data of Table S1, the environmental risk characteristics of the PCB degradation products showed a maximum increase of $421.71 \%$. Therefore, the environmental risk of the PCB plant degradation products was the highest. Improving the degradation of PCBs by plants is of great significance for environmental health. In addition, the change of environmental risk of the microbial products in all the PCB degradation products is relatively small, indicating that microbial degradation methods have little impact on secondary environmental pollution. The microbial anaerobic degradation method has certain advantages over the microbial aerobic degradation method. The phytotoxicity of anaerobic degradation products was higher than that of aerobic degradation products, and other properties were improved than that of the aerobic degradation products.

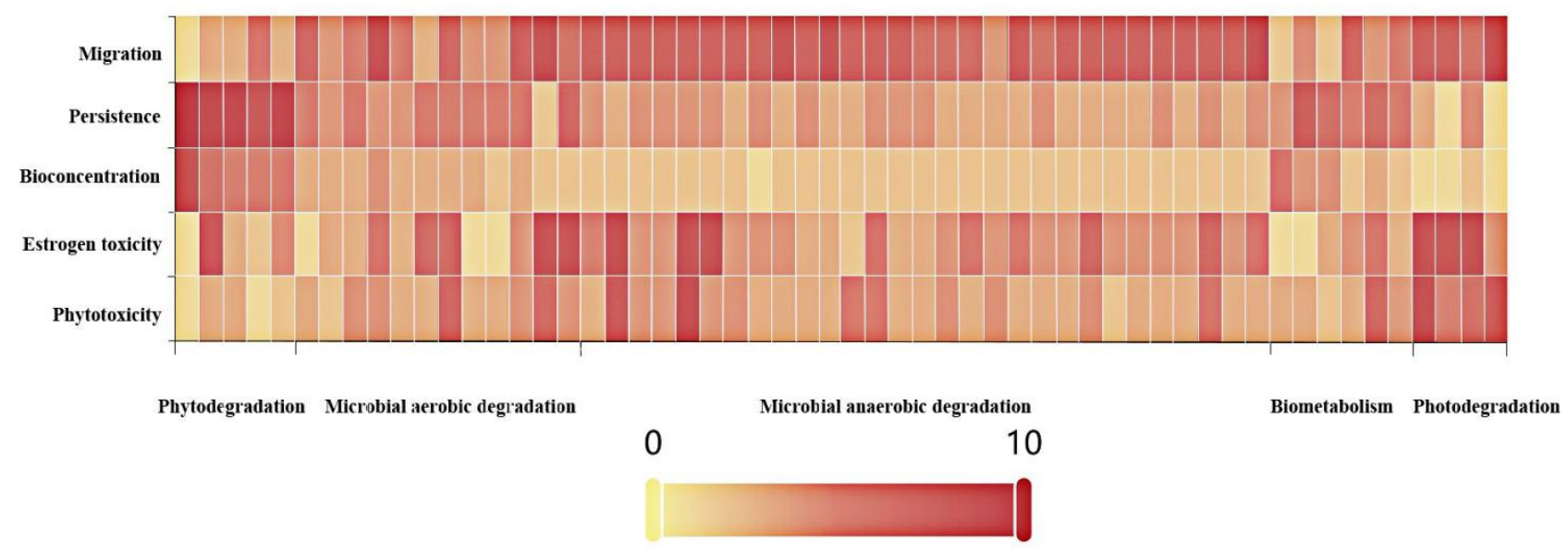

Figure 4. Environmental risk characteristics of the PCB transformation products under different degradation pathways.

In summary, the environmental risk characteristics of PCB degradation products were increased in different degrees under different degradation pathways, which, for the future, indicates that the environmental risk characteristics of PCB degradation products should not be neglected.

\subsection{The Estimation of the Environmental Risk Characteristics of Environmentally Friendly PCB Transformation Products in Plants}

In this study, the environmental risk of the PCB phytodegradation products was the highest. Environmentally friendly PCB derivatives refer to those PCB molecules whose functions remain unchanged and environmental risk characteristics (such as the representative characteristics of persistent organic pollutants) are improved by the design method of molecular modification. Considering the phytodegradation pathway as an example, some environmentally friendly PCB derivatives were designed in different studies $[16,32,33]$, and their parent molecules (low migration environmentally friendly derivative P1 and the parent molecule PCB-52, low bioconcentration environmentally friendly derivative P2, and the parent molecule PCB-189, and low toxicity environmentally friendly derivative P3 and the parent molecule PCB-209) were selected for analyzing the environmental risks. The specific path inference of the molecules is shown in Figure 5. 

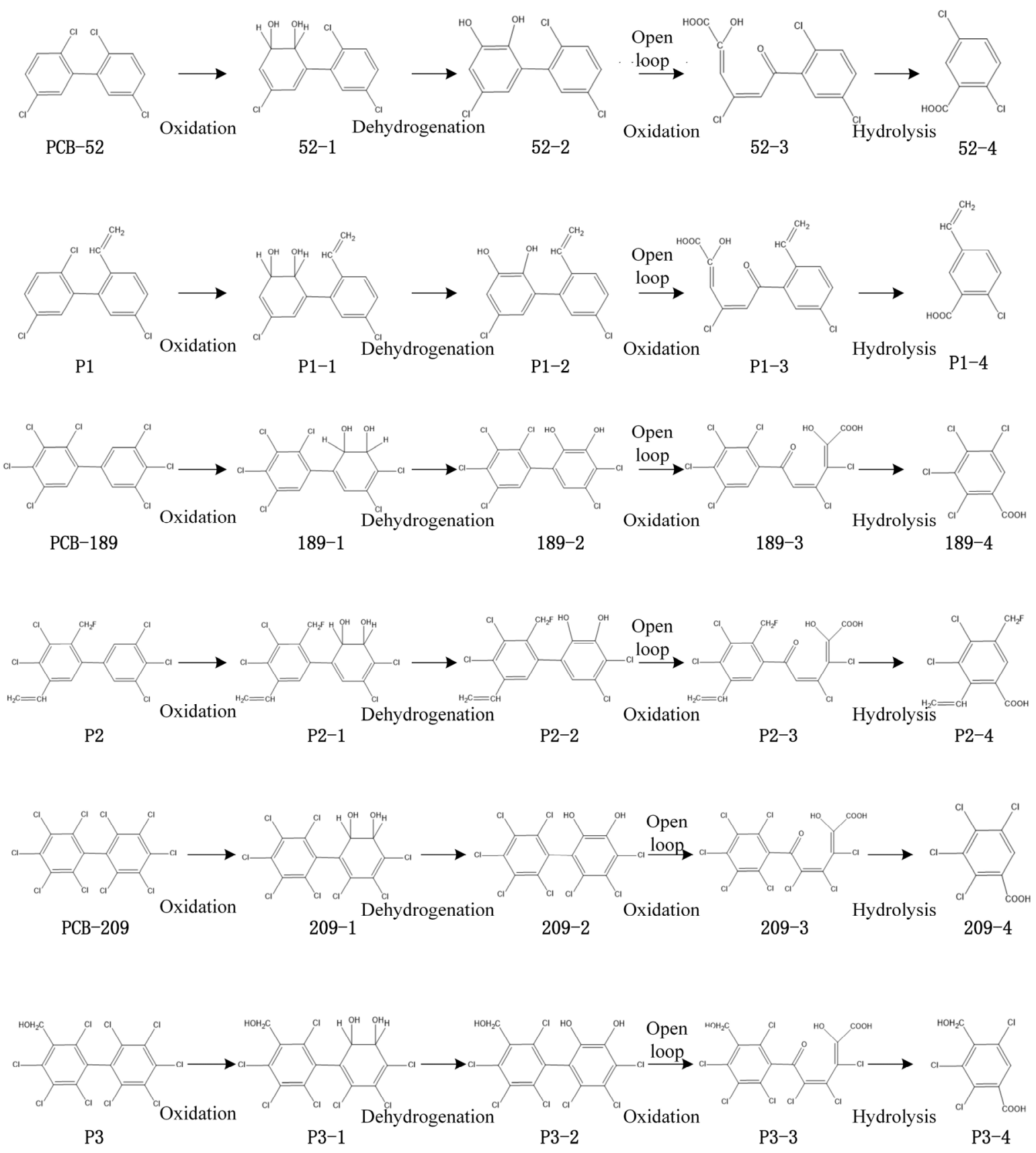

Figure 5. Schematic diagram of the phytodegradation products of three PCBs and their environmentally friendly derivatives.

The higher the parameter value of migration is, the lower the risk of physical environment will be. The other four environmental risk characteristic parameters showed contrary characteristics. As shown in Table 3, the ranges of phytotoxicity, estrogen toxicity, bioconcentration, persistence, and mobility of the phytodegradation products of the three PCBs (PCB-52, PCB-189, and PCB-209) were $-63.71 \%$ to $34.98 \%,-13.84$ to $29.36 \%,-74.97 \%$ to $16.03 \%,-184.02 \%$ to $11.43 \%$, and -61.55 to $18.42 \%$, respectively. Though the environmental risk of most of the PCB degradation products has been reduced, the environmental risk of some products is still increasing. The target organism of phytotoxicity, estrogen toxicity, and bioconcentration of the PCBs is focused on the human body. The increased phytotoxicity represents that the transformation products of PCBs, for example, they may enter the human body through the food chain and, finally, increase the threat to human health [34]. The increase of estrogen toxicity also represents that the transformation products of PCBs interfere with the health of the human endocrine system and affect the normal 
expression of estrogen [35]. The bioconcentration also represents the enrichment ability of the transformation products of PCBs in the human body. The greater the enrichment degree, the stronger the harm to the human body [36]. The persistence effect of the transformation products of PCBs is also implied in the human body and organism in the environment. The long-term existence of the transformation products of PCBs will damage the health of the human body or organism exposed to the environment of PCB metabolites [37], and the migration effect of the transformation products of PCBs also includes the human body or organism far away from the contaminated environment, which represents the long-distance mobility of the transformation products of PCBs in the atmosphere. The research shows that, in Arctic seabirds and Greenland sharks, PCBs were detected at certain concentrations [38,39], indicating that, once the transformation products of PCB conversion products flow into the environment, they will have long-distance migration and cause risks to the environment health. Therefore, as compared to the parent compounds of PCBs, the migration characteristics of phytodegradation products of the three PCBs showed the highest increase in environmental risks, and the variation range was up to $61.55 \%$, which indicates that, when the migration ability of PCB degradation products is improved once they flow into the environment, there is a risk of long-distance migration. The potential risk of long-range migration of the transformation products of PCBs cannot be completely overcome by controlling their parent's migration capacities.

The variations of phytotoxicity, estrogenic toxicity, bioconcentration, persistence, and migration of the three environmentally friendly PCB derivatives (P1, P2, and P3) of the phytodegradation products were estimated to range from $-18.33 \%$ to $21.81 \%,-21.60$ to $40.81 \%,-23.06 \%$ to $60.65 \%,-49.06 \%$ to $13.65 \%$, and -22.46 to $117.32 \%$, respectively. Similarly, the environmental risk of some degradation products was observed to increase. As compared to the parent molecules of the environmentally friendly PCB derivatives, their phytodegradation products showed the best bioconcentration performance. The results showed that the risk of bioconcentration of the PCB degradation products was increased. The bioconcentrations of PCBs in breast milk in urban areas in China were 2.66-3.90 pg/g [36] and, in the adipose tissue of Belgians, were 490-ng/g lipid weight [40]. The accumulation of PCBs in the human body increases with age and, hence, can indirectly cause visceral [41], endocrine [42], and reproductive diseases [43]. Therefore, the control of the bioconcentration ability of environmentally friendly PCB derivatives should not be neglected. 
Table 3. The environmental risk statistics of the three PCBs and their environmentally friendly derivative phytodegradation products.

\begin{tabular}{|c|c|c|c|c|c|c|c|c|c|c|}
\hline Molecular & Phytotoxicity & $\begin{array}{c}\text { Change Rate } \\
(\%)\end{array}$ & $\begin{array}{l}\text { Estrogen } \\
\text { Toxicity }\end{array}$ & $\begin{array}{c}\text { Change Rate } \\
(\%)\end{array}$ & Bioconcentration & $\begin{array}{c}\text { Change Rate } \\
(\%)\end{array}$ & Persistence & $\begin{array}{c}\text { Change Rate } \\
(\%)\end{array}$ & Migration & $\begin{array}{c}\text { Change Rate } \\
(\%)\end{array}$ \\
\hline PCB-52 & 67.203 & & 64.519 & & 4.63 & & 0.989 & & 8.538 & \\
\hline 52-1 & 90.708 & 34.98 & 65.576 & 1.64 & 3.879 & -16.22 & 1.011 & 2.22 & 9.061 & 6.13 \\
\hline $52-3$ & 58.492 & -12.96 & 55.954 & -13.28 & 5.372 & 16.03 & 1.102 & 11.43 & 9.431 & 10.46 \\
\hline $52-4$ & 39.965 & -40.53 & 69.928 & 8.38 & 1.159 & -74.97 & -0.831 & -184.02 & 3.449 & -59.60 \\
\hline P1 & 65.259 & & 69.296 & & 5.477 & & 0.811 & & 9.686 & \\
\hline P1-1 & 65.134 & -0.19 & 54.331 & -21.60 & 5.258 & -4.00 & 0.665 & -18.00 & 8.575 & -11.47 \\
\hline P1-3 & 79.052 & 21.14 & 68.901 & -0.57 & 4.214 & -23.06 & 0.78 & -3.82 & 8.634 & -10.86 \\
\hline P1-4 & 76.850 & 17.76 & 56.281 & -18.78 & 4.596 & -16.09 & 0.893 & 10.11 & 8.852 & -8.61 \\
\hline$\overline{\mathrm{PC}} \overline{-}-\overline{189}$ & $\overline{8} 8.1 \overline{4} 7^{-}$ & & $6 \overline{6} . \overline{0} 5 \overline{2}$ & & $\overline{5} . \overline{4} 4 \overline{0}$ & & $1.5 \overline{6} 7^{-}$ & & $\overline{11} . \overline{5} 1 \overline{7}-$ & \\
\hline 189-1 & 84.575 & -4.05 & 62.105 & -5.98 & 5.446 & 0.11 & 1.274 & -18.70 & 10.565 & -8.27 \\
\hline $189-2$ & 79.545 & -9.76 & 58.150 & -11.96 & 5.649 & 3.84 & 1.599 & 2.04 & 10.912 & -5.25 \\
\hline $189-3$ & 84.176 & -4.50 & 68.607 & 3.87 & 5.939 & 9.17 & 1.299 & -17.10 & 10.702 & -7.08 \\
\hline $189-4$ & 31.989 & -63.71 & 59.291 & -10.24 & 2.873 & -47.19 & -0.558 & -135.61 & 4.428 & -61.55 \\
\hline P2 & 71.373 & & 49.398 & & 3.446 & & 1.311 & & 4.642 & \\
\hline P2-1 & 75.601 & 5.92 & 69.555 & 40.81 & 4.439 & 28.82 & 0.694 & -47.06 & 7.406 & 59.54 \\
\hline P2-3 & 80.525 & 12.82 & 50.002 & 1.22 & 4.725 & 37.12 & 1.49 & 13.65 & 9.046 & 94.87 \\
\hline P2-4 & 86.936 & 21.81 & 58.514 & 18.45 & 5.536 & 60.65 & 1.212 & -7.55 & 10.088 & 117.32 \\
\hline$\overline{\mathrm{PC}} \overline{\mathrm{B}}-\overline{2} \overline{\mathrm{C}}$ & $\overline{7} 9.408^{-}$ & & $5 \overline{4} . \overline{9} 8 \overline{2}$ & & $\overline{6} . \overline{1} 3 \overline{6}$ & & $-\overline{2.19} 1^{-}$ & & $\overline{11} . \overline{8} 0 \overline{5}$ & \\
\hline 209-1 & 85.844 & 8.10 & 50.643 & -7.89 & 4.726 & -22.98 & 1.85 & -15.56 & 10.003 & -15.26 \\
\hline $209-2$ & 77.534 & -2.36 & 51.355 & -6.60 & 6.204 & 1.11 & 2.079 & -5.11 & 9.816 & -16.85 \\
\hline $209-3$ & 61.850 & -22.11 & 47.372 & -13.84 & 6.079 & -0.93 & 1.606 & -26.70 & 10.169 & -13.86 \\
\hline $209-4$ & 50.929 & -35.86 & 71.124 & 29.36 & 3.190 & -48.01 & -0.487 & -122.23 & 7.964 & -32.54 \\
\hline P3 & 75.056 & & 57.487 & & 5.500 & & 1.863 & & 11.102 & \\
\hline P3-1 & 63.598 & -15.27 & 48.786 & -15.14 & 5.815 & 5.73 & 1.700 & -8.75 & 9.383 & -15.48 \\
\hline P3-2 & 79.836 & 6.37 & 58.633 & 1.99 & 5.703 & 3.69 & 1.478 & -20.67 & 9.948 & -10.39 \\
\hline P3-3 & 61.300 & -18.33 & 58.633 & 1.99 & 5.367 & -2.42 & 1.402 & -24.75 & 8.608 & -22.46 \\
\hline P3-4 & 79.556 & 6.00 & 52.530 & -8.62 & 5.065 & -7.91 & 0.949 & -49.06 & 10.965 & -1.23 \\
\hline
\end{tabular}


Figure 6 is an effect diagram that represents the changes in the environmental characteristics of PCB conversion products. In Figure 6, the size of the sphere represents the activity value of each molecule. Comparing the size of the sphere, the final phytodegradation product of P1 represents the low mobility derivative of PCB-52 (Figure 6). As compared to the final phytodegradation product of PCB-52, the migration of the final P1 phytodegradation product is still lower. This result is found to be consistent with the design concept $[16,32,33]$. In addition, the estrogenic toxicity and the migration of the final P1 phytodegradation product also showed a significant improvement as compared to the final PCB-52 phytodegradation product. The improvement in estrogen toxicity and migration were estimated as $19.52 \%$ and $156 \%$, respectively. As compared to the final degradation product of low bioconcentration derivative P2, the final PCB-189 degradation products showed no improvement in terms of the bioconcentration properties and improvement in the estrogen toxicity and migration properties. It was observed that the phytotoxicity of P3 was improved compared to PCB-209, but the environmental risk of the final product was increased. The environmental risk of P3 was higher as compared to PCB-209 in biotoxicity, but the environmental risk of the final product was significantly improved by $26.14 \%$. In addition, the migration of the final $\mathrm{P} 3$ product was improved up to $37.68 \%$.

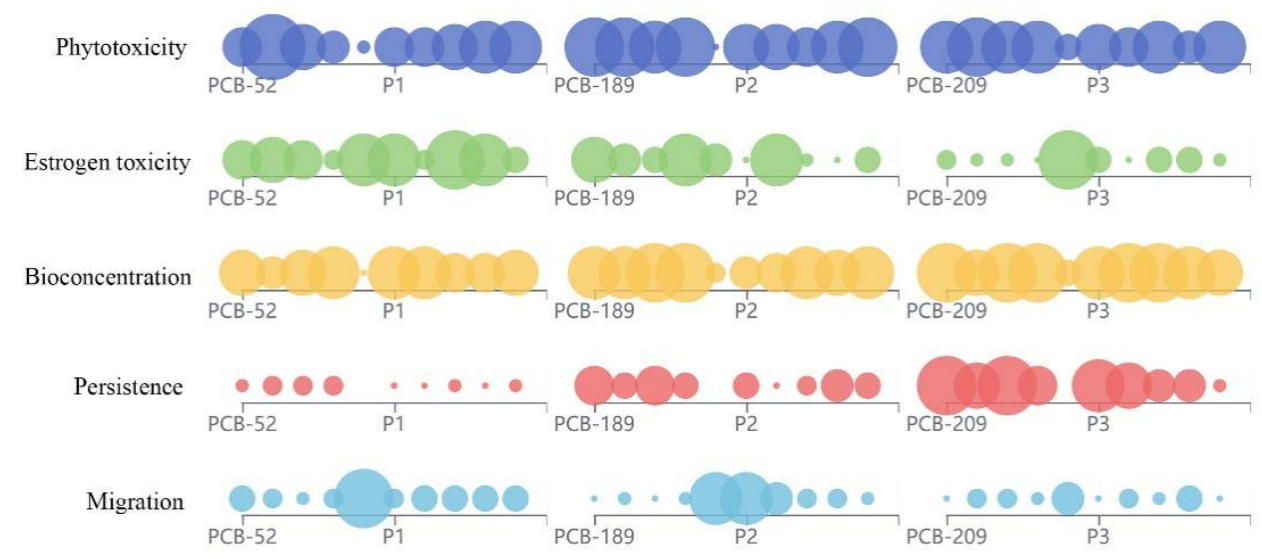

Figure 6. Changes in the environmental characteristics of PCB conversion products.

In summary, the environmental risks of the final degradation products of environmentally friendly PCB derivatives P1 and P2 showed improvements, agreeing with the modification results. However, some degradation products still showed an increase in environmental risks, indicating that the environmental risk control of the PCB degradation products and their environmentally friendly derivatives cannot be neglected. The potential environmental risk of PCBs cannot be completely controlled by the theoretical modification of single environmental characteristics. Therefore, the environmental risks of the transformed products of the environmentally friendly PCB derivatives are also required to be considered.

\subsection{The Validation of the Total Score and Its Estimated Value of PCBs and Their Products Containing Different Chemical Structure}

The phytotoxicity value and estrogen toxicity value of parent PCBs are derived from the total score after docking with the corresponding enzymes. Taking the phytotoxicity and estrogen toxicity as examples, we calculated the total score of the PCBs and their metabolites containing different chemical structures (such as $-\mathrm{OH},-\mathrm{SO}_{2} \mathrm{CH}_{3}$, etc.) in the manuscript and analyzed the correlation and relative error between the total score and the estimated value by the 3D-QSAR model (Table 4). The results showed that the correlation coefficient $r$ between the total cost of 33 molecular estrogen toxicities and their predicted values was 0.547 , which met the correlation coefficient test standard (i.e., when $p=0.001$, the correlation limit value $r_{0}$ is 0.539 ). However, the correlation coefficient $r$ between the total cost of the phytotoxicity of 33 molecules and their estimated values was only 0.369 , 
the correlation was relatively lower, which only met the correlation coefficient test standard when $p=0.05$ (the correlation limit value $\mathrm{r}_{0}$ is 0.339 ). Most of the relative errors were within the allowable range, only one-third of the molecules having a relative error more than $10 \%$.

Table 4. The total score and its estimated value of PCBs and their metabolites containing different chemical structures.

\begin{tabular}{|c|c|c|c|c|c|c|c|}
\hline \multirow[b]{2}{*}{ NO. } & & \multicolumn{3}{|c|}{ Phytotoxicity } & \multicolumn{3}{|c|}{ Estrogen Toxicity } \\
\hline & & Total Cost & Estimated & $\begin{array}{l}\text { Relative } \\
\text { Error (\%) }\end{array}$ & Total Cost & Estimated & $\begin{array}{l}\text { Relative } \\
\text { Error (\%) }\end{array}$ \\
\hline 1 & $4^{\prime}-\mathrm{OH}-\mathrm{CB} 97$ & 75.468 & 71.34 & -5.47 & 66.793 & 55.05 & -17.58 \\
\hline 2 & $4^{\prime}-\mathrm{OH}-\mathrm{CB} 101$ & 74.627 & 62.36 & -16.44 & 65.252 & 59.60 & -8.66 \\
\hline 3 & 4-OH-CB107 & 78.598 & 84.60 & 7.64 & 67.165 & 67.39 & 0.34 \\
\hline 4 & 4-OH-CB109 & 75.046 & 67.77 & -9.70 & 65.372 & 59.92 & -8.34 \\
\hline 5 & 3-OH-CB118 & 86.550 & 83.53 & -3.49 & 62.666 & 63.70 & 1.65 \\
\hline 6 & 4-OH-CB148 & 68.485 & 66.70 & -2.61 & 71.272 & 55.92 & -21.54 \\
\hline 7 & 3-OH-CB153 & 72.700 & 78.53 & 8.02 & 66.310 & 59.69 & -9.98 \\
\hline 8 & 4-OH-CB162 & 97.896 & 85.20 & -12.97 & 61.408 & 64.24 & 4.61 \\
\hline 9 & $4^{\prime}-\mathrm{OH}-\mathrm{CB} 172$ & 80.308 & 66.42 & -17.29 & 65.140 & 55.88 & -14.22 \\
\hline 10 & 4-OH-CB187 & 75.115 & 72.69 & -3.23 & 63.185 & 52.85 & -16.36 \\
\hline 11 & $4^{\prime}-\mathrm{OH}-\mathrm{CB} 199$ & 79.422 & 85.35 & 7.46 & 60.988 & 62.00 & 1.66 \\
\hline 12 & 4-OH-CВ202 & 77.024 & 69.99 & -9.13 & 55.911 & 56.65 & 1.32 \\
\hline 13 & $3^{\prime}-\mathrm{MeSO}_{2}-\mathrm{CB} 49$ & 72.948 & 67.66 & -7.25 & 67.760 & 56.88 & -16.06 \\
\hline 14 & $4-\mathrm{MeSO}_{2}-\mathrm{CB} 64$ & 71.831 & 62.72 & -12.68 & 61.242 & 52.25 & -14.68 \\
\hline 15 & $3-\mathrm{MeSO}_{2}-\mathrm{CB} 70$ & 86.872 & 78.98 & -9.08 & 72.756 & 66.08 & -9.18 \\
\hline 16 & 3-MeSO $2-\mathrm{CB} 110$ & 80.192 & 67.57 & -15.74 & 78.504 & 62.03 & -20.98 \\
\hline 17 & $4-\mathrm{MeSO}_{2}-\mathrm{CB} 149$ & 83.809 & 81.80 & -2.40 & 58.452 & 54.16 & -7.34 \\
\hline 18 & $4-\mathrm{MeSO}_{2}-\mathrm{CB} 174$ & 80.324 & 72.89 & -9.26 & 54.488 & 55.18 & 1.27 \\
\hline 19 & P1 & 66.228 & 65.26 & -1.46 & 70.507 & 69.30 & -1.72 \\
\hline 20 & P1-1 & 104.434 & 65.13 & -37.63 & 58.480 & 54.33 & -7.10 \\
\hline 21 & P1-2 & 78.201 & 70.87 & -9.38 & 73.265 & 73.99 & 0.99 \\
\hline 22 & P1-3 & 85.788 & 79.05 & -7.85 & 67.833 & 68.90 & 1.57 \\
\hline 23 & P1-4 & 78.552 & 76.85 & -2.17 & 52.126 & 56.28 & 7.97 \\
\hline 24 & $\mathrm{P} 2$ & 77.873 & 71.37 & -8.35 & 60.337 & 49.40 & -18.13 \\
\hline 25 & P2-1 & 83.167 & 75.60 & -9.10 & 77.099 & 69.56 & -9.78 \\
\hline 26 & P2-2 & 73.239 & 67.16 & -8.30 & 72.490 & 52.34 & -27.79 \\
\hline 27 & P2-3 & 88.294 & 80.53 & -8.80 & 65.488 & 50.00 & -23.65 \\
\hline 28 & P2-4 & 80.868 & 86.94 & 7.50 & 64.082 & 58.51 & -8.69 \\
\hline 29 & P3 & 77.512 & 75.06 & -3.17 & 63.670 & 57.49 & -9.71 \\
\hline 30 & P3-1 & 78.478 & 63.60 & -18.96 & 53.482 & 48.79 & -8.78 \\
\hline 31 & P3-2 & 76.342 & 79.84 & 4.58 & 63.270 & 58.63 & -7.33 \\
\hline 32 & P3-3 & 76.683 & 61.30 & -20.06 & 72.835 & 58.63 & -19.50 \\
\hline 33 & P3-4 & 77.896 & 79.56 & 2.13 & 55.943 & 52.53 & -6.10 \\
\hline
\end{tabular}

The above results indicate that, indeed, the 3D-QSAR model constructed by the parent PCBs data is slightly lesser accurate in estimating PCBs with different chemical structures and their metabolites. Most of the relative errors are negative, indicating that the 3DQSAR model has indeed underestimated the toxicity of PCBs with different chemical structures and their metabolites, which should actually be higher than those estimated values. However, since the purpose is to measure the environment risk of PCB metabolites on a relative scale, the overall trend of toxicity of the PCB metabolites is consistent with the estimation in this study. The overall analysis of the results is reasonable in the manuscript.

\section{Conclusions}

In this paper, the transformation pathways of PCBs (phytodegradation, microbial degradation, biometabolism, and photodegradation) were derived. The constructed 3DQSAR models were used for estimating the POP characteristics (toxicity (phytotoxicity and biotoxicity), bioconcentration, migration, and persistence) of PCBs and their transformed products. In addition, for the environmental risk evaluation of PCBs and their environmen- 
tally friendly derivative transformation products, the plant degradation pathway with the highest environmental risk increase was selected. The environmental risk of some PCBs and their derivative degradation products was observed to be increased, which indicated that the environmental risk control of PCBs and their environmentally friendly derivative degradation products could not be neglected. The potential environmental risk of PCBs cannot be completely controlled by theoretical modification considering single environmental characteristics. Therefore, the environmental risks of the transformed products of environmentally friendly PCBs are also required to be considered.

Supplementary Materials: The following are available online at https:/ / www.mdpi.com/article/10 .3390/toxics9090213/s1: Table S1: Estimated statistics of the environmental risk characteristics of PCBs and their transformation products.

Author Contributions: Conceptualization, Data curation, Software, and Writing-Original Draft: M.L.; Investigation and Methodology: W.H.; Investigation and Methodology: H.Y.; Writing-Review and Editing: S.S.; and Supervision and Writing-Review and Editing: Y.L. All authors have read and agreed to the published version of the manuscript.

Funding: This research received no external funding.

Institutional Review Board Statement: Not applicable.

Informed Consent Statement: Not applicable.

Conflicts of Interest: The authors declare no conflict of interest.

\section{References}

1. Tanabe, S. PCB problems in the future: Foresight from current knowledge. Environ. Pollut. 1988, 50, 5-28. [CrossRef]

2. Novakova, M.; Mackova, M.; Chrastilova, Z.; Viktorova, J.; Macek, T. Cloning the bacterial bphC gene into Nicotiana tabacum to improve the efficiency of PCB phytoremediation. Biotechnol. Bioeng. 2009, 102, 29-37. [CrossRef]

3. Uchida, E.; Ouchi, T.; Suzuki, Y.; Yoshida, T.; Habe, H.; Yamaguchi, I.; Omori, T.; Nojiri, H. Secretion of bacterial xenobioticdegrading enzymes from transgenic plants by an apoplastic expressional system: An applicability for phytoremediation. Environ. Sci. Technol. 2005, 39, 7671-7677. [CrossRef]

4. Sylvestre, M. Genetically modified organisms to remediate polychlorinated biphenyls. Where do we stand? Int. Biodeter. Biodegr. 2004, 54, 153-162. [CrossRef]

5. Abramowicz, D.A.; Brannan, M.J.; Dort, H.M.V.; Gallagher, E.L. Factors influencing the rale of polychlorinated biphenyls dechlorlnation in Hudson River sediments. Environ. Sci. Technol. 1993, 27, 1125-1131. [CrossRef]

6. Tien, M.; Kirk, T.K. Lignin-degrading enzyme from the hymenomycete Phanerochaete chrysosporium burds. Science 1983, 221, 661-663. [CrossRef]

7. Stapleton, H.M.; Letcher, R.J.; Baker, J.E. Metabolism of PCBs by the deep-water sculpin (Myoxocephalus thompsoni). Environ. Sci. Technol. 2001, 35, 4747-4752. [CrossRef]

8. Ghosh, J.P.; Achari, G.; Langford, C.H. Reductive Dechlorination of PCBs Using Photocatalyzed UV Light. Acta Hydrochim. Hydrobiol. 2012, 40, 455-460. [CrossRef]

9. Grimm, F.A.; Hu, D.; Kania-Korwel, I.; Lehmler, H.J.; Ludewig, G.; Hornbuckle, K.C.; Duffel, M.W.; Bergman, Å.; Robertson, L.W. Metabolism and metabolites of polychlorinated biphenyls. Crit. Rev. Toxicol. 2015, 45, 245-272. [CrossRef]

10. Specker, J.L.; Sullivan, C.V. Vitellogenesis in fishes: Status and perspectives. In Perspectives in Comparative Endocrinology; Davey, K.G., Peter, R.E., Tobe, S.S., Eds.; National Research Council Canada: Ottawa, ON, Canada, 1994; pp. 304-315.

11. Sumpter, J.P.; Jobling, S. Vitellogenesis as a biomarker for estrogenic contamination of the aquatic environment. Environ. Health Persp. 1995, 103, 173-178.

12. Connor, K.; Ramamoorthy, K.; Moore, M.; Mustain, M.; Chen, I.; Safe, S.; Zacharewski, T.; Gillesby, B.; Joyeux, A.; Balaguer, P. Hydroxylated polychlorinated biphenyls (PCBs) as estrogens and antiestrogens: Structure activity relationships. Toxicol. Appl. Pharm. 1997, 145, 111-123. [CrossRef]

13. Al-Anati, L.; Viluksela, M.; Strid, A.; Bergman, Å.; Andersson, P.L.; Stenius, U.; Högberg, J. Hydroxyl metabolite of PCB 180 induces DNA damage signaling and enhances the DNA damaging effect of benzo[a]pyrene. Chem.-Biol. Interact. 2015, 239, 164-173. [CrossRef]

14. Machala, M.; Bláha, L.; Lehmler, H.J. Toxicity of hydroxylated and quinoid PCB metabolites: Inhibition of gap junctional intercellular communication and activation of aryl hydrocarbon and estrogen receptors in hepatic and mammary cells. Chem. Res. Toxicol. 2004, 17, 340-347. [CrossRef]

15. Letcher, R.J.; Klasson-Wehler, E.; Bergman, A. The Handbook of Environmental Chemistry, Volume 3K: Anthropogenic Compounds; Springer: Heidelberg, Germany, 2000; pp. 315-359. 
16. Li, M.H.; Wang, X.L.; Chu, Z.H.; Li, Y. Multiple-Site Molecular Modification of Dioxin-like PCB-189 to Eliminate Bioconcentration. Pol. J. Environ. Stud. 2021, 30, 1655-1675. [CrossRef]

17. Chen, Y.; Cai, X.; Jiang, L.; Li, Y. Prediction of octanol-air partition coefficients for polychlorinated biphenyls (PCBs) using 3D-QSAR models. Ecotoxicol. Environ. Safe 2016, 124, 202-212. [CrossRef]

18. Xu, Z.; Chen, Y.; Qiu, Y.; Gu, W.; Li, Y. Prediction of Stability for Polychlorinated Biphenyls in Transformer Insulation Oil Through Three-dimensional Quantitative Structure-activity Relationship Pharmacophore Model and Full Factor Experimental Design. Chem. Res. Chin. Univ. 2016, 32, 348-356. [CrossRef]

19. Wang, X.; Chen, S.; Wan, K.; Yin, X.; Yang, Y. Altitude distributions and source analysis of OCPs and PCBs in surface soils of Changbai Mountain, Northeast China. Bull. Environ. Contam. Toxicol. 2017, 98, 798-804. [CrossRef] [PubMed]

20. Zhang, C.; Yao, F.; Liu, Y.W.; Chang, H.Q.; Li, Z.J.; Xue, J.M. Uptake and translocation of organic pollutants in plants: A review. J. Integr. Agric. 2017, 16, 1659-1668. [CrossRef]

21. Sylvestre, M.; Macek, T.; Mackova, M. Transgenic plants to improve rhizoremediation of polychlorinated biphenyls (PCBs). Curr. Opin. Biotechnol. 2009, 20, 242-247. [CrossRef]

22. Gibbs, B.F. Enhanced Degradation of Polychlorinated Biphenyls by Surfactants and a Dioxygenase Enzyme Complex; Concordia University: Montreal, QC, Canada, 2007.

23. Seah, S.Y.; Labbé, G.; Nerdinger, S.; Johnson, M.R.; Snieckus, V.; Eltis, L.D. Identification of a serine hydrolase as a key determinant in the microbial degradation of polychlorinated biphenyls. J. Biol. Chem. 2000, 275, 15701-15708. [CrossRef]

24. Gervold, S.K.F.; May, H.D.; Sowers, K.R. Microbial reductive dechlorination of aroclor 1260 in baltimore harbor sediment microcosms is catalyzed by three phylotypes within the phylum chloroflexi. Appl. Environ. Microb. 2007, 73, 3009-3018. [CrossRef]

25. Chang, F.; Chiu, T.; Yen, J.; Wang, Y. Dechlorination pathways of ortho-substituted PCBs by UV irradiation in n-hexane and their correlation to the charge distribution on carbon atom. Chemosphere 2003, 51, 775-784. [CrossRef]

26. Borja, J.; Taleon, D.M.; Auresenia, J.; Gallardo, S. Polychlorinated biphenyls and their biodegradation. Process. Biochem. 2005, 40, 1999-2013. [CrossRef]

27. Pan, L.L. Contamination of Polychlorinated Biphenyls in Agricultural Soils from the Yangtze River Delta and Their Metabolic Pathway in Rice. Ph.D. Thesis, Zhejiang University, Hangzhou, China, 2018.

28. Wekhof, A. Treatment of contaminated water, air and soil with UV flashlamps. Environ. Prog. Sustain. 1991, 10, 241-247. [CrossRef]

29. Huang, Y.; Su, X.O.; Wang, R.G.; Zhang, W. Advances on hydroxylated polychlorinated biphenyls metabolites and the estrogenic effects. Asian J. Ecotoxicol. 2018, 13, 58-68.

30. Guo, L. Study on the Degradation Characteristics of Polychlorinated Biphenyls by Rhodococcus Biphenylivorans TG9. Master's Thesis, Zhejiang University, Hangzhou, China, 2018.

31. Wang, Z.H. Photodegradation of PCBs in Anionic Surfactant (SDS) Solution. Master's Thesis, Hunan University, Changsha, China, 2002.

32. Li, M.H.; Zhang, W.H.; Hou, Y.L.; Sun, R.H.; Li, Y. A Novel 3D-QSA ${ }^{2}$ R Model Assisted with a Log-Normalized Method and Its Application in Molecule Modification. Pol. J. Environ. Stud. 2020, 29, 3675-3682. [CrossRef]

33. Li, M.H.; Li, Y. A Vector Normalized Method-assisted 3D-QSA ${ }^{2}$ R Model and Its Application in the Molecular Modification of PCBs with Higher Flame Retardancy and Lower Toxicity. Sci. Adv. Mater. 2021, 13, 80-87. [CrossRef]

34. He, J.; Zhou, T.; Young, J.C.; Young, J.C.; Boland, G.J.; Scott, P.M. Chemical and biological transformations for detoxification of trichothecene mycotoxins in human and animal food chains: A review. Trends Food. Sci. Technol. 2010, 21, 67-76. [CrossRef]

35. Winneke, G.; Walkowiak, J.; Lilienthal, H. PCB-induced neurodevelopmental toxicity in human infants and its potential mediation by endocrine dysfunction. Toxicology 2002, 181, 161-165. [CrossRef]

36. Shen, H.; Ding, G.; Wu, Y.; Pan, G.; Zhou, X.; Han, J.; Li, J.; Wen, S. Polychlorinated dibenzo-p-dioxins/furans (PCDD/Fs), polychlorinated biphenyls (PCBs), and polybrominated diphenyl ethers (PBDEs) in breast milk from Zhejiang, China. Environ. Int. 2012, 42, 84-90. [CrossRef] [PubMed]

37. Megson, D.; Sullivan, O.G.; Comber, S.; Worsfold, P.J.; Lohan, M.C.; Edwards, M.R.; Shields, W.J.; Sandau, C.D.; Patterson, J.D.G. Elucidating the structural properties that influence the persistence of PCBs in humans using the National Health and Nutrition Examination Survey (NHANES) dataset. Sci. Total Environ. 2013, 461-462, 99-107. [CrossRef] [PubMed]

38. Hegseth, M.N.; Camus, L.; Helgason, L.B.; Bocchetti, R.; Gabrielsen, G.W.; Regoli, F. Hepatic antioxidant responses related to levels of PCBs and metals in chicks of three Arctic seabird species. Comp. Biochem. Physiol. Part C 2011, 154, 28-35. [CrossRef] [PubMed]

39. Marco, V.; Stefano, Z.; Elena, A.; Carlo, B.; Andrea, G.; Rossano, P. Polychlorinated biphenyls (PCBs) and polybrominated diphenyl ethers (PBDEs) in Antarctic ice-free areas: Influence of local sources on lakesand soils. Microchem. J. 2015, 120, 26-33.

40. Covaci, A.; Voorspoels, S.; Roosens, L.; Jacobs, W.; Blust, R.; Neels, H. Polybrominated diphenyl ethers (PBDEs) and polychlorinated biphenyls (PCBs) in human liver and adipose tissue samples from Belgium. Chemosphere 2008, 73, 170-175. [CrossRef]

41. Chen, X.; Chen, J.S.; Zhang, L.; Li, J.G.; Yao, L.; Self, S.G.; Sun, X.; Tang, N.J. Levels of PCDDs, PCDFs and dl-PCBs in the blood of childbearing-aged women living in the vicinity of a chemical plant in Tianjin: A primary study. Chemosphere 2015, 118, 1-4. [CrossRef] [PubMed] 
42. Gauger, K.J.; Kato, Y.; Haraguchi, K.; Lehmler, H.J.; Robertson, L.W.; Bansal, R.; Zoeller, R.T. Polychlorinated biphenyls (PCBs) exert thyroid hormone-like effects in the fetal rat brain but do not bind to thyroid hormone receptors. Environ. Health Persp. 2004, 112, 516-523. [CrossRef] [PubMed]

43. Meeker, J.D.; Hauser, R. Exposure to Polychlorinated Biphenyls (PCBs) and Male Reproduction. Syst. Biol. Reprod. Med. 2010, 56, 122-131. [CrossRef] 